\title{
THE KEY FACTORS OF SELECTING ELECTRONICS MANUFACTURING SERVICE SUPPLIERS - AN EXAMPLE OF COMPANY U IN TAIWAN
}

\author{
Hui-Feng Chiu ${ }^{1}$, Tzong-Ru (Jiun-Shen) Lee ${ }^{1}$, Ching-Kuei Kao ${ }^{2}$ \\ ${ }^{1}$ National Chung Hsing University, Department of Marketing, Taiwan \\ ${ }^{2}$ Hsing-Kuo University of Management, Department of Marketing and Logistics Management, Taiwan
}

\author{
Corresponding author: \\ Tzong-Ru (Jiun-Shen) Lee \\ National Chung Hsing University \\ Department of Marketing \\ 250 Kuo Kuang Rd., Taichung 402, Taiwan R.O.C. \\ phone: +886-04-22840393\#766 \\ e-mail:trlee@dragon.nchu.edu.tw
}

Received: 7 July 2015

Accepted: 3 September 2015

\begin{abstract}
In a highly competitive environment with a developed network, the customers of electronics manufacturing service (EMS) manufacturers always seek a wide range of choices. EMS manufacturers can attract loyal customers and establish long-term partnerships if they understand and satisfy their customers' needs to execute a response plan successfully with limited resources. If these conditions are met, EMS manufacturers can create high customer equity. This study investigates how the demand of downstream enterprises can be satisfied on the basis of the opinion of upstream suppliers in the electronics manufacturing industry. Domestic and foreign literature related to the dimensions and elements of supplier evaluation criteria were investigated to extract 22 elements of supplier selection by corporate customers. Five supplier evaluation dimensions were then established through interviews with the internal experts of the case company. An analytic hierarchy process-based (AHPbased) approach is used to design the questionnaire for the external corporate customers of the case company. The questionnaire is then used to investigate the supplier evaluation criteria of the customers of EMS manufacturers. Conclusions and suggestions are provided on the basis of the results to provide the case company with references that can be used to develop and maintain customer relationship and create high customer equity.
\end{abstract}

KEYWORDS

Electronics Manufacturing Service, Evaluation Criteria, AHP-based Approach, Key Factors.

\section{Introduction}

An increasing number of high-technology enterprises have completely outsourced their production process, including production and manufacturing, after-sale services, and product development, in response to the shrinking global profit margin. These enterprises retain technologies with core competitive advantages and transfer non-critical production technology to negotiate with factories for specialization and to reduce cost [1]. The traditional Taiwan electronics contract industry provides original equipment manufacturers (OEM) and original design manufacturers (ODM) to foreign commission manufactur- ers [2]. The service content of OEMs and ODMs is a simple assembly processing. Thus, competitors can be replaced easily. In response to declining profits and stiff international competition, electronics contract manufacturing companies in Taiwan offer electronics manufacturing services (EMS) to provide an original global logistics channel and global subcontract assembly so as to reduce cost. MMI [3] reported that four manufacturers from Taiwan are included in the top 20 EMS companies and that 17 of the top 30 EMS companies are located in Asia. Hence, Asian countries are expected to continuously play an extremely important role in EMS in the future. The International Data Corporation (IDC) [4] and 
New Venture Research (NVR) [5] predicted that the output value of the global contract industry (including EMS and ODM) would reach $\$ 413$ and $\$ 654$ billion in 2015 and 2016, respectively. Both the IDC [4] and NVR [5] predicted a $6.2 \%$ to $10 \%$ growth in the output of the global manufacturing service industry from 2012 to 2016 under the challenge of global logistics management. These institutes also opined that the EMS outsourcing pattern has become an important competitive pattern in the EMS industry.

At present, Taiwanese EMS manufacturers endure global competition and pressure because of the continuous improvement of technology. The corporate customers of EMS manufacturers prefer to have a wide range of choices. In this context, enterprises must understand the demands of their customers under rapid changes in competitive conditions and establish a response plan to satisfy such demands. By achieving these objectives, these enterprises can eventually increase the number of their loyal customers, establish long-term cooperation and partnerships, compete with strong competitors, and generate high customer equity to create the high anticipated revenue of the customer for present and future. EMS manufacturers must also develop and implement an effective supply chain management method. However, this undertaking can only be efficiently realized by first selecting reliable suppliers. Suitable suppliers that can be contracted for production strategy, technical support, and cost reduction can be selected with a set of supplier evaluation criteria, which must be established by each industry at the outset. Accordingly, the present study analyzes the evaluation criteria adopted by downstream corporate customers in selecting suppliers and the opinions of upstream suppliers in the electronics manufacturing industry. Moreover, this study implements such criteria to extrapolate which criterion and elements should be realized and understood by the evaluated upstream suppliers so that they can establish effective sales strategies in the future.

The commonly adopted supplier criteria are mostly based on multiple criteria [6]. Chen [7] adopted the analytic network process (ANP) [8] as a supplier evaluation method. Chen et al. [9] introduced the analytic hierarchy process (AHP) to simplify complicated problems in the element-level system by establishing levels and to help decision makers select the most appropriate program. An AHP-based approach [10] is adopted in the current study to investigate the supplier evaluation criteria used by the customers of EMS manufacturers. This approach is preferred to avoid the addition of personal preferences for large subjective elements and to identify the most appropriate program. The elements that influence supplier evaluation are properly classified.

An EMS factory in Taiwan, one of the leading manufacturers in global DMS, is regarded as an example in the current study [3]. A questionnaire is designed to collect data from the external corporate customers of the case company. An AHP-based approach is used to analyze the external corporate customers, as this method mainly depends on partial inheritance, full inheritance, and fully independent inheritance when calculating the evaluation criteria. Importance sorting is conducted on the basis of weight values. Therefore, the results and suggestions obtained with the AHP-based approach are expected to increase the confidence of the case company in employing appropriate strategies.

The rest of this paper is organized into six sections. Following the Introduction, Sec. 2 establishes the evaluation criteria stipulated in the literature. Section 3 presents the design of the questionnaire for the AHP-based approach. Section 4 discusses the development of the said questionnaire design. Section 5 examines the evaluation results of the AHP-based approach, and Sec. 6 concludes the study.

\section{Literature review}

Numerous studies have investigated the process of selecting supplier evaluation criteria for the electronics manufacturing industry [11-16]. Shyur and Shih [14] extracted seven supplier evaluation criteria using the ANP, which is adopted by manufacturing enterprises, to provide such firms with references for selecting high-quality and reliable suppliers. Huang and Keskar [12] extracted seven supplier selection dimensions for OEMs by employing the AHP as supplier evaluation criteria because corporate customers tend to consider outsourcing strategies. Ting and Cho [15] integrated "supplier evaluation" and "procurement decisions" among manufacturers that produce computer motherboards to help enterprises obtain effective solutions for measuring different objectives in complicated decision-making environments. In their study, 6 dimensions and 16 evaluation criteria were extracted through the AHP. Lee et al. [13] examined the companies that manufacture computer hard disks and established four dimensions. These dimensions were considered as the classification standard of supplier evaluation factors. Then, they used the ANP to extract a second set of supplier evaluation criteria to establish a competitive supply chain and long-term partnership, as well as to enhance core technical capabilities. Garfamy [11] established five measuring standards of suppli- 
er evaluation by studying 719 European enterprises. Yang [16] extracted five supplier evaluation criteria via factor analysis and adopted a conjunctive method to select the most appropriate supplier. Finally, a multi-criteria decision-making mode was employed to investigate a well-known manufacturer of computer peripherals in Taiwan. The current supplier evaluation procedure of this particular company was also investigated.

The above discussion indicates that the clearly defined element factors are maintained. Table 1 illustrates the integration of similar items based on the definition and introduction of the evaluation criteria found in the literature. In the present research, these 22 elements are sorted to serve as the basis of the supplier evaluation criteria. The corresponding dimension items of these elements are then sorted prior to implementing the AHP-based approach to investigate the supplier evaluation criteria of corporate customers. Following the work of Lemon et al. [17], this study establishes three dimension items (i.e., quality, price, and convenience). However, the supplier evaluation factors extracted from Table 1 cannot be completely controlled, classified, and explained. Thus, the seven senior managers of seven corporate customers with the most significant contribution to the case company are interviewed.
Most experts have suggested that "convenience" must be replaced with "service level" to provide a clear meaning to the term. Experts have also proposed adding two dimension items, namely, "customer relationship" and "organizational ability". The manufacturers in the electronics outsourcing industry that act as suppliers should continuously invest resources to maintain customer relationship, develop new customers, or strengthen long-term cooperation. Thus, enterprises must develop their technology, capital, and other basic organizational abilities. As for suppliers, they must have their own professional human resources, adequate equipment, and flexible service processes to improve customer satisfaction when goods are delivered to various parts of the world. This approach could enable suppliers to provide convenient and effective services to their end customers and establish mutual trust and longterm partnership with them. Therefore, customer relationship and organizational ability are important for upstream suppliers. The 22 items for supplier evaluation are arranged after integrating the positive suggestions provided by experts. In particular, these items are arranged according to quality condition, service level, customer relationship, organization capability, and cost/price.

Table 1

Elements for supplier evaluation criteria.

\begin{tabular}{|c|c|c|c|}
\hline Dimension & Element & Definition & Source \\
\hline \multirow[t]{4}{*}{ Quality condition (A) } & $\begin{array}{l}\text { Provision of excellent pro- } \\
\text { duction quality }(\mathrm{A}-1)\end{array}$ & $\begin{array}{l}\text { Strict management of each process and effective con- } \\
\text { trol of the production of defective products to achieve } \\
\text { excellence. }\end{array}$ & {$[11,12,14,15]$} \\
\hline & $\begin{array}{l}\text { Consistent product quality } \\
(\mathrm{A}-2)\end{array}$ & $\begin{array}{l}\text { Production of products even with limited resources ac- } \\
\text { cording to the quality level approved by both parties. }\end{array}$ & {$[11-13,15,16]$} \\
\hline & $\begin{array}{l}\text { Ownership of international } \\
\text { quality certificates }(\mathrm{A}-3)\end{array}$ & $\begin{array}{l}\text { Ownership of international professional quality certifi- } \\
\text { cates, establishment of environmental protection poli- } \\
\text { cies, and full demonstration of the responsibility and } \\
\text { commitment of international citizens }\end{array}$ & {$[11,12,15]$} \\
\hline & $\begin{array}{l}\text { Open and transparent qual- } \\
\text { ity system (A-4) }\end{array}$ & $\begin{array}{l}\text { Excellent information control system, strict monitor- } \\
\text { ing, and correct execution of quality rate. }\end{array}$ & {$[11-13]$} \\
\hline \multirow[t]{4}{*}{ Service level (B) } & $\begin{array}{l}\text { Rapid and reliable resilience } \\
\text { in responding to customer } \\
\text { demand }(\mathrm{B}-1)\end{array}$ & $\begin{array}{l}\text { Shortening the response time to customer demand to } \\
\text { improve customer satisfaction and rapidly addressing } \\
\text { changes in customer demand to obtain customer trust }\end{array}$ & {$[11,12,14-16]$} \\
\hline & $\begin{array}{l}\text { Improved product after- } \\
\text { sales system (B-2) }\end{array}$ & $\begin{array}{l}\text { Provision of complete after-sales service to assist and } \\
\text { improve corporate image. }\end{array}$ & {$[11,15,16]$} \\
\hline & $\begin{array}{l}\text { Provision of reliable } \begin{array}{l}\text { and } \\
\text { professional human }\end{array} \\
\text { source services }(\mathrm{B}-3)\end{array}$ & $\begin{array}{l}\text { Provision of stable and professional human resource } \\
\text { services to meet customer requirements. }\end{array}$ & {$[11,13-15]$} \\
\hline & $\begin{array}{l}\text { Prevention and manage- } \\
\text { ment of possible risks (B-4) }\end{array}$ & $\begin{array}{l}\text { Assisting customers in dealing with product abnormal- } \\
\text { ities and managing relative risk elements (such as nat- } \\
\text { ural and man-made disasters) to reduce customer loss. }\end{array}$ & {$[11,13]$} \\
\hline
\end{tabular}


Table 1 [Cont.]

Elements for supplier evaluation criteria.

\begin{tabular}{|c|c|c|c|}
\hline Dimension & Element & Definition & Source \\
\hline Service level (B) & $\begin{array}{l}\text { Delivery effectiveness with } \\
\text { high degree of adaptability } \\
\text { and reliability (B-5) }\end{array}$ & $\begin{array}{l}\text { Adherence to the delivery time specified by } \\
\text { customers and the delivery of correct quanti- } \\
\text { ties to ensure customer equity and benefits. }\end{array}$ & {$[11,12,14-16]$} \\
\hline \multirow[t]{4}{*}{ Customer relationship (C) } & $\begin{array}{l}\text { Information exchange and } \\
\text { experience sharing (C-1) }\end{array}$ & $\begin{array}{l}\text { Provision of full and open information and op- } \\
\text { portunities for sharing to customers. }\end{array}$ & {$[11,13]$} \\
\hline & $\begin{array}{l}\text { Good relationships among } \\
\text { high-level managers }(\mathrm{C}-2)\end{array}$ & $\begin{array}{l}\text { Improvement in the interaction among high- } \\
\text { level managers of enterprises to produce a } \\
\text { sense of intrigue and brotherhood and to at- } \\
\text { tain mutual cooperation }\end{array}$ & {$[11,13]$} \\
\hline & $\begin{array}{l}\text { Maintenance of stable rela- } \\
\text { tionships among enterprises } \\
\text { (C-3) }\end{array}$ & $\begin{array}{l}\text { Approved business demand based on commu- } \\
\text { nication and understanding to maintain busi- } \\
\text { ness relationship. }\end{array}$ & {$[11,13,15]$} \\
\hline & $\begin{array}{l}\text { Complementarity among } \\
\text { enterprises (C-4) }\end{array}$ & $\begin{array}{l}\text { Enterprises becoming life communities with } \\
\text { complementary interests in response to the de- } \\
\text { mand of this business mode. }\end{array}$ & {$[11,13]$} \\
\hline \multirow[t]{5}{*}{ Organization ability (D) } & $\begin{array}{l}\text { Innovating and improving } \\
\text { manufacturing technology } \\
\text { constantly (D-1) }\end{array}$ & $\begin{array}{l}\text { Promoting innovation in manufacturing and } \\
\text { improving the quality of internal company ac- } \\
\text { tivities to meet industry standards and to } \\
\text { ensure the adaptability of the manufacturing } \\
\text { technology to customer demand. }\end{array}$ & {$[11,13,14]$} \\
\hline & $\begin{array}{l}\text { High-quality production } \\
\text { equipment and high capac- } \\
\text { ity (D-2) }\end{array}$ & $\begin{array}{l}\text { Possession of high-quality production equip- } \\
\text { ment and high capacity to meet the constantly } \\
\text { changing demands of customers at any time. }\end{array}$ & {$[11-13]$} \\
\hline & $\begin{array}{l}\text { Collaborative research and } \\
\text { development and technolog- } \\
\text { ical innovation (D-3) }\end{array}$ & $\begin{array}{l}\text { Establishment of a balance between new prod- } \\
\text { uct demand and customer demand and im- } \\
\text { provement in the capability of the organization } \\
\text { to research, develop, and innovate constantly. }\end{array}$ & {$[11,13,15]$} \\
\hline & $\begin{array}{l}\text { Strong financial manage- } \\
\text { ment performance (D-4) }\end{array}$ & $\begin{array}{l}\text { Good financial management performance that } \\
\text { can be accessed and evaluated by the public } \\
\text { (e.g., cash flow, accounts receivable, accounts } \\
\text { payable, and assets and liabilities). }\end{array}$ & {$[11,13,15]$} \\
\hline & $\begin{array}{l}\text { Effective and systematic } \\
\text { downstream supplier man- } \\
\text { agement (D-5) }\end{array}$ & $\begin{array}{l}\text { Possession of adequate bargaining power, co- } \\
\text { operation with downstream suppliers, and full } \\
\text { control over the supply of key materials and } \\
\text { the sharing of important market information. }\end{array}$ & {$[11,13-15]$} \\
\hline \multirow[t]{4}{*}{ Cost/price (E) } & $\begin{array}{l}\text { Assisting customers to re- } \\
\text { duce purchase cost (E-1) }\end{array}$ & $\begin{array}{l}\text { Strong ability to bargain, comply with (adapt) } \\
\text { customer demands, and reduce purchase (ma- } \\
\text { terials) cost. }\end{array}$ & {$[11,13-16]$} \\
\hline & $\begin{array}{l}\text { Avoidance of transfer cost } \\
(\mathrm{E}-2)\end{array}$ & $\begin{array}{l}\text { Release of products with reasonable prices and } \\
\text { excellent quality and satisfy delivery time to } \\
\text { avoid high operating cost and the transfer of } \\
\text { customers to other suppliers in avoidance of } \\
\text { management risks. }\end{array}$ & {$[11-13,15]$} \\
\hline & $\begin{array}{l}\text { Continuous reduction of } \\
\text { production cost }(\mathrm{E}-3)\end{array}$ & $\begin{array}{l}\text { Continuous improvement in production effi- } \\
\text { ciency, increase in product quality, and control } \\
\text { over the cost of physical (assets) and intangible } \\
\text { (human resources) assets to reduce production } \\
\text { costs. }\end{array}$ & {$[11-13,15]$} \\
\hline & $\begin{array}{l}\text { Effective management and } \\
\text { control of inventory loss } \\
\text { cost (E-4) }\end{array}$ & $\begin{array}{l}\text { Highly effective inventory management and } \\
\text { control to reduce the cost generated by the use } \\
\text { of unsuitable materials. }\end{array}$ & {$[12,13,15]$} \\
\hline
\end{tabular}

\section{Questionnaire design}

The case company in Taiwan was established more than 30 years ago. According to MMI [3], the case company is a leading EMS manufacturer. The turnover of seven major corporate enterprises shows that the case company provides manufacturing services that account for $70 \%$ of the total turnover. The case company receives purchase orders from corporate customers to produce final and semi-final products through a series of communication, production, testing, and quality management activities. These 
products are based on the specifications and quantities indicated by its customers. The case company delivers goods according to the date, quantity, and place specified by its customers. In this section, the hierarchical structure is created, and the AHP-based approach is utilized to investigate the elements of the supplier evaluation criteria of the case company

\section{Hierarchical structure of AHP-based approach}

This study aims to identify the elements of the supplier evaluation criteria. The addition of individual preferences, which cause subjective factors, is avoided. The most appropriate solution for reducing poor decisions is selected to simplify and systematize the procedure. The AHP-based approach is applied to investigate the supplier evaluation criteria of the corporate customers.

With the AHP-based approach, the complicated supplier evaluation factors in Table 1 are divided into systematic structures labeled as Levels 1, 2, and 3 on the basis of their attribute correlations. A quantitative method is employed to perform effective decision making and sequencing (Fig. 1).

The AHP-based approach is then utilized to construct a paired comparison matrix method on the basis of a measurement scale for sort values. Instead of using the traditional ratio scale of the AHP approach, the paired comparison matrix method is adopted to calculate the weights of the evaluation criteria [8]. This method can also be used to identify fuzzy and ambiguous evaluation criteria. Therefore, it is adopted in this work to solve the adverse effects of having too many levels.

The questionnaire for this approach is developed to construct an AHP-based hierarchical structure and to divide each level into comparison matrix blocks. The matrix is designed with a paired comparison form on the basis of the comparison matrix blocks. Such design is aimed at allowing each respondent to evaluate sort values according to the degree of importance and to fully express the degree of importance of each evaluation criterion. The questionnaires are distributed to gather feedback from the respondents. The retrieved questionnaires are arranged according to the paired comparison matrix, and the weights and consistency values of each evaluation criterion in the comparison matrix are calculated. The partial inheritance, full inheritance, and fully independent inheritance are used to calculate, rank, and analyze the weights of the evaluation criteria [10]. The best supplier evaluation method and criteria are then selected on the basis of the analysis of the evaluation results to investigate and analyze the elements identified by customers.

\section{Questionnaire design \\ for AHP-based approach}

The evaluation criteria in the paired comparison matrix are designed on the basis of pairwise comparisons. The respondents are asked to sort the evaluation criteria from 1 to 3 according to their degrees of influence. The factor with the highest influence is scored 1, whereas the factor with the second highest influence is scored 2 . The remaining items are scored similarly. The questionnaire contents are divided into the following parts:

1. Part One: The questionnaire design of the main dimension is developed according to the five dimensions of Level 2 in Fig. 1. The respondents are asked to rank the five dimensions from 1 to 5 , where (1) means very important and (5) means very unimportant.

2. Part Two: This part of the questionnaire mainly investigates the effect of the Level 3 dimensions on the elements of supplier evaluation on the basis of the influence of the Level 2 dimensions (Fig. 1). With quality condition as an example, the respondents are asked to rank four elements (A-1, A-2, A-3, and A-4) from 1 to 4 according to their intuition. In the ranking, (1) means very important, and (4) means very unimportant

3. Part Three: The 22 elements of Level 3 in Figure 1 are arranged. The respondents are then asked to rank the 22 elements from 1 to 22 according to their intuition. In this ranking, (1) means very important, and (22) means very unimportant. This procedure is implemented to investigate the relationship among the evaluation criteria in Level 3 after excluding the influence of the evaluation dimensions in Level 2.

The AHP-based approach is utilized to create a questionnaire survey for two to three grassroots-level senior managers of the top seven corporate customers with external contact units. These customers provided the highest contribution to the annual turnover of the case company in 2010. The total turnover of the top seven corporate customers during that period accounted for about $70 \%$ of the annual turnover of the case company. From the 80 questionnaires distributed, 72 are retrieved (recovery rate of 90\%) 
Management and Production Engineering Review

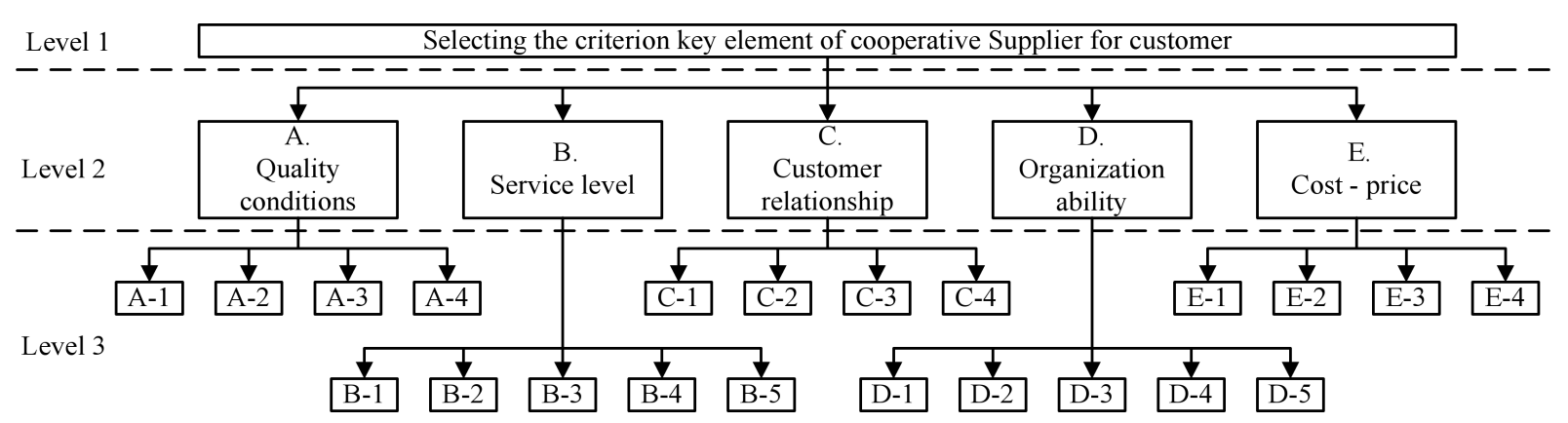

Fig. 1. Hierarchical structure of the selection of the key elements of the cooperative supplier criteria of customers.

\section{Analysis of questionnaire results}

In this section, the evaluation results of the AHPbased approach are discussed.

\section{Evaluation result}

The calculation of the dimensions and factor weights, the evaluation criteria, and the results of the AHP-based approach are explained below.

\section{Calculation of dimensions and factor weights}

The questionnaire has a hierarchical structure. The evaluation criteria in each matrix block are designed according to the paired comparison to understand the importance of each level in the matrix blocks and to compare the importance of two evaluation criteria. The paired comparison matrix is established (Table 2) according to the average of the evaluated sort values of the questionnaire and the evaluation value of the relative importance of the new sort values. The values are arranged into a matrix by utilizing the sort values in the columns as the denominator and the sort values in the rows as the numerator to identify the paired comparison matrix in the Level 2 dimension. A low score is assigned to a small sort value. A small weight indicates that an item is important.

The weight $\left(W_{i}^{\prime}\right)$ can be calculated according to the paired comparison matrix in Table 2. Quality condition (A) has the highest degree of influence among the Level 2 evaluation dimensions, followed by cost or price (E), service level (B), and customer relationship $(\mathrm{C})$. Organization capability $(\mathrm{D})$ has the least influence.

The consistency and reliability of the paired comparison matrix are verified by calculating the consistency index $(\mathrm{CI})$ and consistency ratio $(\mathrm{CR})$. In Level 2 , CI $=-1.2066$, which complies with $\mathrm{CI} \leqq 0.1$ and $\mathrm{CR}=-1.077$. The last value complies with $\mathrm{CR} \leqq 0.1$. Thus, the data in Level 2 are consistent. The overall weight of the elements in Level 3 is analyzed after establishing the weights of all the elements in Level 2.

2. Evaluation criteria for the AHP-based approach

The selection of the evaluation criteria is established on the basis of the importance of each evaluation criterion in the entire evaluation. The evaluation method utilized to calculate each element weight and the overall weight in Level 3 is based on the three research hypotheses raised in [10], namely, (1) partial inheritance, (2) full inheritance, and (3) fully independent inheritance.

Table 2

Paired comparison matrix in Level 2.

\begin{tabular}{|c|c|c|c|c|c|c|c|c|c|}
\hline \multicolumn{7}{|c|}{ Paired comparison matrix } & \multirow{3}{*}{$W_{i}$} & \multirow{3}{*}{$W_{i}^{\prime}$} & \multirow{3}{*}{ Rank } \\
\hline \multicolumn{2}{|r|}{ Rank } & 1 & 3 & 4 & 5 & 2 & & & \\
\hline & Level 2 & $\begin{array}{l}\text { A. Quality } \\
\text { condition }\end{array}$ & $\begin{array}{l}\text { B. Service } \\
\text { level }\end{array}$ & $\begin{array}{l}\text { C. Customer } \\
\text { relationship }\end{array}$ & $\begin{array}{l}\text { D. Organization } \\
\text { ability }\end{array}$ & $\begin{array}{l}\mathrm{E} . \text { Cost } \\
\text { price }\end{array}$ & & & \\
\hline 1 & A. Quality condition & 1.00 & 0.33 & 0.25 & 0.20 & 0.50 & 0.384 & 0.067 & 1 \\
\hline 3 & B. Service level & 3.00 & 1.00 & 0.75 & 0.60 & 1.50 & 1.152 & 0.200 & 3 \\
\hline 4 & C. Customer relationship & 4.00 & 1.33 & 1.00 & 0.80 & 2.00 & 1.535 & 0.267 & 4 \\
\hline 5 & D. Organization ability & 5.00 & 1.67 & 1.25 & 1.00 & 2.50 & 1.919 & 0.333 & 5 \\
\hline 2 & E. Cost price & 2.00 & 0.67 & 0.50 & 0.40 & 1.00 & 0.768 & 0.133 & 2 \\
\hline \multicolumn{7}{|c|}{ SUM } & 5.758 & 1.000 & \\
\hline
\end{tabular}

Remarks: $W_{1}=0.384=\sqrt[5]{1.00 \times 0.33 \times 0.25 \times 0.2 \times 0.50}, W_{1}^{\prime}=0.067=0.384 / 5.758$. 


\section{(1) Partial inheritance}

The weights and consistency of the paired comparison matrix in Level 3 are confirmed prior to calculating partial inheritance. On the basis of the concept of calculating $W_{i}^{\prime}$, the weights $\left(W_{i}^{\prime \prime}\right)$ of the five dimensions in Level 3 are calculated, as shown in Table 3. As provided in Table 3, CI $=-1.2596$ in the dimensions of quality condition, customer relationship, and cost/price, whereas CI $=-1.2066$ in the dimensions of service level and organizational capability. Both values comply with $\mathrm{CI} \leqq 0.1$. Moreover, $\mathrm{CR}=-1.3995$ in the dimensions of quality condition, customer relationship, and cost/price, whereas $\mathrm{CR}=-1.0773$ in the dimensions of service level and organizational capability. Both values also comply with $\mathrm{CR} \leqq 0.1$. Therefore, the evaluation elements in Level 3 are consistent.

Partial inheritance calculates the overall level weight after determining the weight of the elements in all levels to prioritize each evaluation item. The partial inheritance weight relation between the evaluation criteria in Level 2 (main dimension) and those in the next level (i.e., Level 3) is presented in this section. Partial elements are affected by the evaluation dimensions because of the selection of the evaluation criteria by the respondents. The overall weight calculation by partial inheritance is equal to the weight value of the evaluation dimension multiplied by the evaluation criteria weight value in the same dimension.

Table 3

Weights of the evaluated key elements for the five dimensions.

\begin{tabular}{|c|c|c|c|c|c|c|c|c|}
\hline A. Quality condition & A-1 & $\mathrm{A}-2$ & A-3 & A-4 & & $\overline{W_{i}}$ & $W_{i}^{\prime \prime}$ & Rank \\
\hline A-1 & 1.000 & 2.000 & 0.667 & 0.500 & & 0.904 & 0.200 & 2 \\
\hline $\mathrm{A}-2$ & 0.500 & 1.000 & 0.333 & 0.250 & & 0.452 & 0.100 & 1 \\
\hline $\mathrm{A}-3$ & 1.500 & 3.000 & 1.000 & 0.750 & & 1.355 & 0.300 & 3 \\
\hline $\mathrm{A}-4$ & 2.000 & 4.000 & 1.333 & 1.000 & & 1.807 & 0.400 & 4 \\
\hline SUM & & & & & & 4.518 & 1.000 & \\
\hline B. Service level & B-1 & B-2 & B-3 & B-4 & B-5 & $\overline{W_{i}}$ & $W_{i}^{\prime \prime}$ & Rank \\
\hline B-1 & 1.000 & 0.500 & 0.200 & 0.333 & 0.250 & 0.384 & 0.067 & 1 \\
\hline B-2 & 2.000 & 1.000 & 0.400 & 0.667 & 0.500 & 0.768 & 0.133 & 2 \\
\hline B-3 & 5.000 & 2.500 & 1.000 & 1.667 & 1.250 & 1.919 & 0.333 & 5 \\
\hline B-4 & 3.000 & 1.500 & 0.600 & 1.000 & 0.750 & 1.152 & 0.200 & 3 \\
\hline B-5 & 4.000 & 2.000 & 0.800 & 1.333 & 1.000 & 1.535 & 0.267 & 4 \\
\hline SUM & & & & & & 5.758 & 1.000 & \\
\hline C. Customer relationship & $\mathrm{C}-1$ & $\mathrm{C}-2$ & $\mathrm{C}-3$ & $\mathrm{C}-4$ & & $\overline{W_{i}}$ & $W_{i}^{\prime \prime}$ & Rank \\
\hline $\mathrm{C}-1$ & 1.000 & 0.667 & 2.000 & 0.500 & & 0.904 & 0.200 & 2 \\
\hline $\mathrm{C}-2$ & 1.500 & 1.000 & 3.000 & 0.750 & & 1.355 & 0.300 & 3 \\
\hline $\mathrm{C}-3$ & 0.500 & 0.333 & 1.000 & 0.250 & & 0.452 & 0.100 & 1 \\
\hline $\mathrm{C}-4$ & 2.000 & 1.333 & 4.000 & 1.000 & & 1.807 & 0.400 & 4 \\
\hline SUM & & & & & & 4.518 & 1.000 & \\
\hline D. Organizational ability & $\mathrm{D}-1$ & $\mathrm{D}-2$ & $\mathrm{D}-3$ & $\mathrm{D}-4$ & $\mathrm{D}-5$ & $W_{i}$ & $W_{i}^{\prime \prime}$ & Rank \\
\hline D-1 & 1.000 & 2.000 & 0.667 & 0.400 & 0.500 & 0.768 & 0.133 & 2 \\
\hline $\mathrm{D}-2$ & 0.500 & 1.000 & 0.333 & 0.200 & 0.250 & 0.384 & 0.067 & 1 \\
\hline D-3 & 1.500 & 3.000 & 1.000 & 0.600 & 0.750 & 1.152 & 0.200 & 3 \\
\hline D-4 & 2.500 & 5.000 & 1.667 & 1.000 & 1.250 & 1.919 & 0.333 & 5 \\
\hline D-5 & 2.000 & 4.000 & 1.333 & 0.800 & 1.000 & 1.535 & 0.267 & 4 \\
\hline SUM & & & & & & 5.758 & 1.000 & \\
\hline E. Cost price & E-1 & E-2 & E-3 & E-4 & & $W_{i}$ & $W_{i}^{\prime \prime}$ & Rank \\
\hline E-1 & 1.000 & 0.250 & 0.500 & 0.333 & & 0.452 & 0.100 & 1 \\
\hline E-2 & 4.000 & 1.000 & 2.000 & 1.333 & & 1.807 & 0.400 & 4 \\
\hline E-3 & 2.000 & 0.500 & 1.000 & 0.667 & & 0.904 & 0.200 & 2 \\
\hline E-4 & 3.000 & 0.750 & 1.500 & 1.000 & & 1.355 & 0.300 & 3 \\
\hline SUM & & & & & & 4.518 & 1.000 & \\
\hline
\end{tabular}


Management and Production Engineering Review

Table 4

Weights of partial inheritance, full inheritance, and fully independent inheritance.

\begin{tabular}{|c|c|c|c|c|c|c|c|c|c|c|}
\hline \multicolumn{2}{|l|}{ Level 2} & \multicolumn{9}{|c|}{ Level 3} \\
\hline \multirow[t]{2}{*}{ Dimension } & \multirow[t]{2}{*}{$W_{i}^{\prime}(X)$} & \multirow[t]{2}{*}{$\begin{array}{c}\text { Evaluative } \\
\text { criteria }\end{array}$} & \multicolumn{3}{|c|}{ Partial inheritance } & \multicolumn{3}{|c|}{ Full inheritance } & \multicolumn{2}{|c|}{$\begin{array}{c}\text { Fully } \\
\text { independent } \\
\text { inheritance }\end{array}$} \\
\hline & & & $W_{i}^{\prime \prime}(Y)$ & $\begin{array}{l}\text { Weight } \\
(X \times Y)\end{array}$ & Rank* & $W_{i}^{\prime \prime}(Y)$ & Rank & $\operatorname{Rank}^{*}$ & $W_{i}^{\prime \prime}$ & Rank* \\
\hline \multirow{4}{*}{ A. Quality condition } & \multirow{4}{*}{0.067} & A-1 & 0.200 & 0.01333 & 2 & 0.200 & 2 & 2 & 0.024 & 6 \\
\hline & & A-2 & 0.100 & 0.00667 & 1 & 0.100 & 1 & 1 & 0.004 & 1 \\
\hline & & A-3 & 0.300 & 0.02000 & 5 & 0.300 & 3 & 3 & 0.020 & 5 \\
\hline & & A-4 & 0.400 & 0.02667 & 8 & 0.400 & 4 & 4 & 0.051 & 8 \\
\hline \multirow{5}{*}{ B. Service level } & \multirow{5}{*}{0.200} & B-1 & 0.067 & 0.01333 & 4 & 0.067 & 1 & 9 & 0.012 & 3 \\
\hline & & B-2 & 0.133 & 0.02667 & 9 & 0.133 & 2 & 10 & 0.047 & 12 \\
\hline & & B-3 & 0.333 & 0.06667 & 17 & 0.333 & 5 & 13 & .055 & 14 \\
\hline & & B-4 & 0.200 & 0.04000 & 11 & 0.200 & 3 & 11 & 0.040 & 10 \\
\hline & & B-5 & 0.267 & 0.05333 & 16 & 0.267 & 4 & 12 & 0.028 & 7 \\
\hline \multirow{4}{*}{ C. Customer relationship } & \multirow{4}{*}{0.267} & C-1 & 0.200 & 0.05333 & 15 & 0.200 & 2 & 15 & 0.032 & 13 \\
\hline & & $\mathrm{C}-2$ & 0.300 & 0.08000 & 19 & 0.300 & 3 & 16 & 0.063 & 16 \\
\hline & & $\mathrm{C}-3$ & 0.100 & 0.02667 & 10 & 0.100 & 1 & 14 & 0.036 & 9 \\
\hline & & $\mathrm{C}-4$ & 0.400 & 0.10667 & 21 & 0.400 & 4 & 17 & 0.083 & 21 \\
\hline \multirow{5}{*}{ D. Organizational ability } & \multirow{5}{*}{0.333} & $\mathrm{D}-1$ & 0.133 & 0.04444 & 13 & 0.133 & 2 & 19 & 0.059 & 15 \\
\hline & & $\mathrm{D}-2$ & 0.067 & 0.02222 & 6 & 0.067 & 1 & 18 & 0.043 & 11 \\
\hline & & $\mathrm{D}-3$ & 0.200 & 0.06667 & 18 & 0.200 & 3 & 20 & 0.071 & 18 \\
\hline & & $\mathrm{D}-4$ & 0.333 & 0.11111 & 22 & 0.333 & 5 & 22 & 0.087 & 22 \\
\hline & & D-5 & 0.267 & 0.08889 & 20 & 0.267 & 4 & 21 & 0.079 & 20 \\
\hline \multirow{4}{*}{ E. Cost/price } & \multirow{4}{*}{0.133} & E-1 & 0.100 & 0.01333 & 3 & 0.100 & 1 & 5 & 0.008 & 2 \\
\hline & & E-2 & 0.400 & 0.05333 & 14 & 0.400 & 4 & 8 & 0.075 & 19 \\
\hline & & E-3 & 0.200 & 0.02667 & 7 & 0.200 & 2 & 6 & 0.016 & 4 \\
\hline & & E-4 & 0.300 & 0.04000 & 12 & 0.300 & 3 & 7 & 0.067 & 17 \\
\hline
\end{tabular}

Table 4 shows that the weight value of quality condition $\left(W_{1}^{\prime}\right)$ is 0.067 . The weight values of the evaluation criteria in Level $3\left(W_{1}^{\prime \prime}\right)$ are 0.200 for A-1, 0.100 for A-2, 0.300 for A-3, and 0.400 for A-4. The matrix in the other levels is established using the same steps. All the calculated weights are then ranked according to their degrees of influence, with the score of 1 being the highest. Therefore, a small weight value in the weight rank indicates high influence. This process provides the evaluation dimensions in Level 2 and the evaluation criteria in Level 3. Thus, the importance of each evaluation criterion in the entire evaluation mode when the weights are under partial inheritance relation can be obtained $\left(\right.$ Rank $\left.^{*}\right)$.

\section{(2) Full inheritance}

The full relationship between Level 2 (main dimension) and the lower level (i.e., Level 3) is then investigated. The respondents are assumed to be affected by the evaluation dimensions in Level 2 when they select the evaluation criteria. The analysis of the full relationship between these two levels is based solely on the sort value of the weight value $\left(W_{i}^{\prime}\right)$ of the evaluation dimensions in Level 2. Such analysis is conducted to determine the order of weights $\left(W_{i}^{\prime \prime}\right)$ of the evaluation criteria in Level 3.

Table 4 shows that the weight values $\left(W_{i}^{\prime}\right)$ of the evaluation dimensions in Level 2 are ranked in the following order: quality condition $\rightarrow$ cost/price $\rightarrow$ service level $\rightarrow$ customer relationship $\rightarrow$ organizational capability. Therefore, the sorting method of the overall evaluation criteria under full inheritance is based on the main dimension, that is, quality condition, to determine the rank of the evaluation criteria in the lower level. The sort value of the evaluation criteria is the sort value in the dimension of quality condition. The sort value of the evaluation criteria in Level 3 of the main dimension is determined in a similar manner. Finally, the weight sorting (Rank*) of all the evaluation criteria is performed.

(3) Fully independent inheritance

The fully independent relation of the weights of the evaluation criteria in Level 3 is examined after excluding the influence of the main dimension element in Level 2. The respondents are assumed to be unaffected by the evaluation dimension in Level 2 
when they select each evaluation criterion. Table 4 shows the weight values $\left(W_{i}^{\prime \prime}\right)$ of all the evaluation criteria in Level 3 and the weight sorting (Rank*) after excluding the influence of the main dimension element in Level 2. The smallest weight value in the sorting represents the factor with the most influence.

\section{Analysis of the evaluation result}

A method is selected from full inheritance, partial inheritance, and fully independent inheritance as the reference for the final evaluation. Two criteria are adopted. The first criterion adopted is the exclusion method. The result with the largest difference from the actual practice of the case company is excluded. The second criterion is determined after the remaining methods are sorted. Daneil's [18] principle is used as reference to extract the top six factors from the sorting results of the remaining methods. After comparison, the result that most significantly matches the actual status of the company is employed as the method.

The exclusion method is implemented for screening. This method is used to obtain the largest sorting value of full inheritance, partial inheritance, and fully independent inheritance. The smallest sorting value is then subtracted to obtain a large difference in the absolute value. The differences are compared and analyzed. Finally, the value that differs most from the actual status of the case company is removed. The following four elements demonstrate large differences

1. D-2 - Corporate customers require their suppliers to be equipped with high-quality production equipment and adequate capacity settings so that the latter could improve product performance and meet technical requirements. Suppliers are also requested to build their facilities near the factories of their customers. They also need to store semiproducts or maintain a safe stock of components and materials because the consumer market is constantly changing. A slight change in one part may affect the entire situation. Suppliers would miss opportunities if they do not prepare their response to market changes. They could even lose corporate customers. Corporate customers inspect a project through supplier audit according to the highest standard. This factor should be prioritized in practice. Thus, the importance of weight sorting obtained by partial inheritance and fully independent inheritance complies with the actual status of the case company.

2. E-2 - The EMS industry has a low entry threshold and many competitors. Special pieces of pro- duction equipment with high precision or technical patents are always supplied by corporate customers. These pieces of equipment are returned to corporate customers when production is terminated. If the cooperative relation with suppliers is terminated, the equipment is transferred to other competitive suppliers because such equipment belongs to corporate customers. The costs of other production equipment with low precision or technical levels are included in the original contract. However, these costs change depending on the current status. Outsourcing manufacturers absorb these costs to obtain orders or to increase customer satisfaction. Therefore, the importance of weight sorting obtained by full inheritance does not comply with the actual status of the company.

3. E-4 - The case company is recognized by other corporate customers in the same industry because of its effective management and control of the cost of inventory loss. Newly added corporate customers constantly compare the ability of established suppliers with that of other competitors in the initial supplier audit. This factor is an important capability that should be developed by suppliers, but it is not prioritized by corporate customers. Thus, the importance of weight sorting obtained by full inheritance does not comply with the actual status of the company.

4. B-5 - The life cycle of electronic products is becoming short while the change in market demand is becoming increasingly large. Thus, corporate customers prefer manufacturing facilities that are located near the market to reduce human effort and transportation cost, as well as to avoid the tariff barriers of international trade and damages resulting from product transportation. Reducing the risk of increased inventory cost resulting from the disappearance of business opportunities when new products fail to penetrate the market is extremely important. Thus, corporate customers constantly ask suppliers to deliver semi-products or components to specified places within specified time periods. This approach is called just-in-time delivery. Each supplier in the supply chain should aim to satisfy the requirements of a corporate customer. Otherwise, the corporate customer will impose a penalty, require compensation, or cancel supplier qualification. Therefore, this factor is a priority for corporate customers. The weight sorting value obtained by fully independent inheritance complies with the actual status of the company.

Full inheritance is excluded because it is significantly different from the actual business operating condition with respect to the four items. The top 
six factors obtained with the other two methods are selected for analysis based on Daneil's principle [18].

Five items among the top six factors sorted by partial inheritance and fully independent inheritance are identified. These items include A-1, A-2, A-3, B-1, and E-1. A-2 and A-3 obtain similar scores. An insignificant difference is observed between partial inheritance and fully independent inheritance. The sorting value obtained by partial inheritance for D-2 is 6 . However, the sorting value obtained by fully independent inheritance for E-3 is 11. The sorting value obtained by fully independent inheritance is 4 , whereas that obtained by partial inheritance is 7 . The analysis of these two items is provided below.

1. D-2 - The electronics manufacturing industry has a low threshold and many competitors. Corporate customers often ask their suppliers to enhance their services and increase service flexibility in response to the drastic changes in market demand. Manufacturers in the supplier chain are reluctant to meet those requirements because of realistic conditions. Equipment and capacity are pre-audit items for supplier evaluation, which focuses on spatial configuration and line planning. Important pieces of production equipment are supplied by corporate customers because of the confidentiality of the business. Thus, advanced technology and excellent process rate become the major demands after batch production. Upstream suppliers who own high-quality production equipment and have adequate capacity settings are important to corporate customers. Corporate customers can dominate by controlling precise machines. Thus, under the current condition, the weight sorting result for D-2 calculated by fully independent inheritance complies with the actual situation in the electronics industry and the case company.

2. E-3 - The case company has been engaged in the electronic manufacturing industry for more than 30 years and belongs to the top 500 companies in the global manufacturing industry. The case company is obviously popular in this industry. Therefore, this company provides excellent production quality and does not emphasize prior evaluation. This finding is verified by A-1, the sorting value of which is 6 in all weights, as determined via fully independent inheritance. Thus, corporate customers require the case company to focus on the continuous reduction of production cost under the same quality condition. In addition, customers require the case company to provide them with profit feedback to help reduce prices and increase market share in the future. The corporate customers of the case company also require suppliers to pro- vide an added value to E-3 under the condition of A-1. In this way, they can compete with numerous competitors and obtain long-term purchase orders. Upstream suppliers must agree and meet the requirements required by corporate customers. Thus, the importance sorting value of E-3 calculated by fully independent inheritance is 4 , which is higher than the weight sorting value of $7 \mathrm{ob}-$ tained by partial inheritance. This finding reflects the actual status of the case company.

The vertical analysis with partial inheritance and fully independent inheritance provides the analysis results for D-2 and E-3. The analysis shows that the weight sorting value of the evaluation criteria calculated with the AHP-based approach and fully independent inheritance complies with the actual status of current corporate customers. Thus, the analysis using fully independent inheritance is used as the basis for the conclusions.

\section{Conclusion}

Understanding customer demand and providing services for customer satisfaction in a highly competitive EMS industry can create loyal customers and establish long-term partnerships. Consequently, enterprises achieve high customer equity. This study sorts 22 items of the supplier evaluation criteria to investigate the requirements of corporate customers and to determine how these requirements can be met. The 22 items are grouped into five dimensions according to the results of the interviews with the internal experts of the case company. These five dimensions are (1) quality condition, (2) service level, (3) customer relationship, (4) organizational capability, and (5) cost/price. These dimensions are used as the basis of the questionnaire design. The questionnaires are then distributed to the external corporate customers of the case company. The recovered questionnaires are analyzed using the AHP-based approach. Five evaluation items are identified from the 22 evaluation factors. These five items (A-1, A-2, B-1, E-1, and E-3) are important criteria of supplier evaluation for both external customers and internal employees. Therefore, the case company should rapidly improve and implement executive strategies that correspond to these five elements to improve customer loyalty and customer satisfaction and to achieve high customer equity.

The purpose of this study is based on the thinking of upstream suppliers in the EMS industry, to explore how to meet the need of downstream customers. In the future, the upstream suppliers in the other industry can use the proposed method to de- 
velop and maintain customers' relation, then the reference of creating higher customer equity and interest is proposed.

\section{References}

[1] Pisano G.P., Wheelwright S.C., The new logic of high tech RESD, Harvard Business Review, 73, 5, 93105, 1995.

[2] Bidault F., Despres C., Butler C., The drivers of cooperation between buyers and suppliers for production innovation, Research Policy, 26, 719-732, 1989.

[3] MMI, The MMI Top 50 for 2011, available at: http://www.mfgmkt.com/mmi-top-50.html, 2011.

[4] IDC, Worldwide IDC Electronics Manufacturing Services Market Forecast (2010-2015), available at: http://www.idc.com/, 2011.

[5] NVR, Market Report - Worldwide Electronics Manufacturing Services, available at: https://www.itri.co.uk/index.php?option=com_zoo \&task=item\&item_id=2494\&Itemid=161, 2012.

[6] Kannan G., Sarkis J., Sivakumar R., Palaniappan M., Multi criteria decision making approaches for green supplier evaluation and selection: a literature review, in Conference on the Greening of Industry Network, GIN, Linkoping-Sweden, 2012.

[7] Chen W.S., Applying evidential reasoning approach to the vendor selection problem, Journal of Technology, 20, 4, 339-355, 2005.

[8] Saaty T.L., The analytic hierarchy process, New York: McGraw Hill, 1980.

[9] Chen X.H., Pan C.L., Huang Y.F., The integration of AHP and ELECTRE in the selection process for the most advantageous bid, Journal of Commercial Modernization, 4, 3, 99-119, 2008.

[10] Sheu J.B., A hybrid fuzzy-based approach for identifying global logistics strategies, Transportation Research Part E: Logistics and Transportation Review, 40, 1, 39-61, 2004.

[11] Garfamy R.M., Supplier selection and business process improvement, International Journal of Services and Operations Management, 5, 2, 233-250, 2009.

[12] Huang S.H., Keskar H., Comprehensive and configurable metrics for supplier selection, International Journal of Production Economics, 105, 2, 510-523, 2007.

[13] Lee A.H.I., Chang H.J., Lin C.Y., An evaluation model of buyer-supplier relationships in high-tech industry - the case of an electronic components manufacturer in Taiwan, Computers \& Industrial Engineering, 57, 4, 1417-1430, 2009.

[14] Shyur H.J., Shih H.S., A hybrid MCDM model for strategic vendor selection, Mathematical and Computer Modelling, 44, 7, 749-761, 2006.

[15] Ting S.C., Cho D.I., An integrated approach for supplier selection and purchasing decisions, Supply Chain Management: An International Journal, 13, 2, 116-127, 2008.

[16] Yang J.L., A study of using multi-criteria evaluation model for vendor selection, in Conference of Industry Business Management and Information Technology, 372-379, 2006.

[17] Lemon K.N., Rust R.T., Zeithaml V.A., What drives customer equity, Marketing Management, 2025, 2001.

[18] Daniel D.R., Management information crisis, Harvard Business Review, 39, 5, 111-121, 1961. 